\title{
Gravimetric Evolution During Sewage Sludge Biostabilization
}

\author{
Paola Posligua ${ }^{1,2,3}$, Michelle Peñaherrera', Elvito Villegas², Carlos Banchón ${ }^{4}$ \\ 1 Universidad de Las Américas (UDLA), Faculty of Engineering and Agrarian Sciences, Environmental \\ Engineering, Av. de los Granados and José Queri, 59302, Quito, Ecuador \\ 2 Universidad Nacional Mayor de San Marcos (UNMSM), 07001, Lima, Perú \\ 3 Instituto Antártico Ecuatoriano (INAE), 59316, 9 de Octubre y Chile, Guayaquil, Ecuador \\ ${ }^{4}$ Universidad Agraria del Ecuador (UAE), Environmental Engineering School, Faculty of Agrarian Sciences, \\ Av. 25 de Julio and P. Jaramillo, 59304, Guayaquil, Ecuador \\ * Corresponding author's e-mail: paolaposligua@gmail.com
}

\begin{abstract}
Sewage sludge is a by-product in the wastewater treatment and is an inherent hazardous issue because of the pathogenic contamination of natural resources. Therefore, in this study, domestic sludge was treated with premontane forest soil, macronutrients, and also pasteurization to reduce the content of volatile solids and pathogens. The best biostabilization treatment using premontane forest soil and pasteurization obtained a volatile solids reduction of $87 \%$ according to the environmental regulations, in which a biosolid is stable in a range of $38 \%$ of volatile solids reduction. In less than 30 days in a mesophilic range, the coliform count was reduced up to $71 \%$ when using forest soil and pasteurization. Thus, a biosolid-class B was obtained using gravimetric means as a platform to promote fast quality control.
\end{abstract}

Keywords: pathogens, biosolids, sewage, mesophilic, anaerobic.

\section{INTRODUCTION}

In the next 40 years, the world population will double and consequently, the capacity to treat the volume of wastewater according to the population increase will barely meet the demand; this would cause the waste to be discharged without known control to ecosystems. Municipal wastewater contains pathogenic bacteria, protozoa, viruses, and parasites, as well as oils, fats, detergents, soaps, nutrients, salts, and particles of hair, food, and paper. The treatment of municipal wastewater accounts for the worldwide production of approx. 48 million dry tons of sewage sludge, and its disposal has become an environmental problem because of the pathogenic risks (Fytili and Zabaniotou, 2008; Krüger et al., 2014; Li et al., 2007; Mu et al., 2016; Snowden-Swan et al., 2016; Wang et al., 2008a; Wei et al., 2003; Zahan et al., 2016). A typical drawback of the wastewater treatment system is the high-energy cost in the context of energy efficiency, carbon footprint, and recycling. Sludge treatment and its disposal account for up to $60 \%$ of the total operating costs, and the elimination of harmful pathogens and a new kind of contaminant, namely, emerging pollutants constitutes a critical step (Barrios et al. 2015; De Vrieze et al., 2016; Jenicek et al., 2012; Lewis et al., 1999; Ruffino et al., 2015; Wang et al., 2008b; Weemaes and Verstraete, 1998; Ye et al., 2014). Biological sewage sludge is mainly composed of organic matter (approx. 59-88\%) from scum or the solids removed in wastewater treatment (Tchobanoglous et al., 2013). Sewage comes from human excreta and is a mixture of fats, proteins, carbohydrates, lignin, amino acids, sugars, cellulose, humic material, fatty acids, non-essential trace metals and organic micropollutants, which can be decomposed and produce offensive odors (Environmental Protection Agency, 1994; Kinney et al., 2006; Rogers, 1996; Singh and Agrawal, 2008; Weemaes and Verstraete, 1998). 
In 1991, the term biosolid was adopted to apply to all sedimentary sludge in which mesophilic or thermophilic digestion diminishes odors, organic matter, and pathogenic risk under anaerobic conditions, which also generates bioenergy (Bright and Healey, 2003; Cain, 2010; Carrère et al., 2010; Snowden-Swan et al., 2016; Zahan et al., 2016). Biosolids have been recognized as a useful soil amendment and source of nitrogen, phosphorus, organic matter, and other nutrients, which can enhance the physical properties of soil as well as plant growth (Kinney et al., 2006); moreover, biosolids contain a good deal of energy at approx. 11,400 BTU per dry pound (Mu et al., 2016). Among Canada, the US, and European countries, 53 percent of biosolids are used in agriculture directly or after composting, totaling more than 2.39 million dry tons per year yield (Kinney et al., 2006; Stasinakis, 2012; Wang et al., 2007). However, biosolids are not completely secure for land application due to offensive odors and toxic elements, e.g., heavy metals and persistent organic pollutants, found in the sewage sludge (Hale et al., 2001; Krach et al., 2008; Lewis et al., 2002; Wei et al., 2003). A total of 87 synthetic organic chemicals were found in biosolids, including chemicals like polychlorinated biphenyls (PCBs), pharmaceuticals such as triclosan (antimicrobial disinfectant), tonalide (a musk fragrance), diphenhydramine (antihistamine), carbamazepine (an antiepileptic drug), and heavy metals like As, $\mathrm{Cd}, \mathrm{Cr}, \mathrm{Pb}, \mathrm{Hg}, \mathrm{Ni}$, and $\mathrm{Se}$ (Barrios et al., 2015; Cain, 2010; Egan, 2013; Mulla et al., 2016; Venkatesan and Halden, 2014). Biosolids also carry high densities of enteric viruses, helminth eggs, and Salmonella spp., which pose risks to the human health (Barrios et al., 2015; Gerba et al., 2011; Oron et al., 2014). Given that a stabilization process should be performed with high-quality standards to prevent the human health risks, the principal contributions in the present study are:

- An anaerobic process to stabilize sewage sludge using pre-treatments under different conditions like the addition of premontane forest soil under differing nutritional conditions and pasteurization.

- A thermogravimetric technique to monitor sludge stabilization.

In the pursuit of testing the hypothesis, we found out that the interactions between the biological, thermal, and salinity treatments influence the change of total and volatile solids, namely a gravimetric evolution of a biostabilization process.

\section{MATERIALS AND METHODS}

\section{Biostabilization process}

Residual sludge was collected from the secondary settler tank of a municipal wastewater treatment plant located in Quito (Ecuador). The residual sludge (A) was thickened by sedimentation (B) with a sedimentation column (2 $\mathrm{m}$ in length and $30 \mathrm{~cm}$ in diameter). Afterwards, the resulting sludge was filtered with cellulose pads (C) and then pre-treated under different conditions (D). The following pre-treatments were made before the anaerobic digestion: $\left(\mathrm{T}_{1}\right) 0.6 \mathrm{~kg}$ of soil from a premontane secondary forest was added per each kg of sludge; $\left(\mathrm{T}_{2}\right)$ again, $0.6 \mathrm{~kg}$ of soil from a premontane forest was added per each $\mathrm{kg}$ of sludge, and also, a $0.1 \%$ nutrient solution of $10 \% \mathrm{~N}, 40 \% \mathrm{P}$ and $10 \% \mathrm{~K}$ (Merck, USA) was added twice daily for 30 days; $\left(\mathrm{T}_{3}\right)$ the sludge was pasteurized in an oven (Wiseven 165, USA) at $70^{\circ} \mathrm{C}$ for 30 minutes; $\left(\mathrm{T}_{4}\right)$ a $0.1 \%$ nutrient solution was added every morning, and a $1.0 \% \mathrm{NaCl}$ solution (Merck, USA) was added at night for 30 days. After pre-treatment, anaerobic digestion was performed in a sealed $1000 \mathrm{~mL}$ Erlenmeyer flask (E). The flasks were thermally insulated and were slowly mixed twice a day for 30 days. At the end of the process, the biosolid was sundried (Figure 1).

\section{Analysis}

The temperature and $\mathrm{pH}$ were measured three times a day using a soil multiparameter tester (HANNA HI 99121, USA). Total solids (ST) and volatile solids content (SV) were determined at $105^{\circ} \mathrm{C}$ and $550^{\circ} \mathrm{C}$, respectively, using ASTM methods. Arsenic, cadmium, mercury, and lead were quantified by atomic absorption according to APHA standard methods. The biological activity of the sludge was measured using OxiTop ${ }^{\circledR}$ Biological Oxygen Demand (BOD) respirometry system (WTW, Germany) at $25^{\circ} \mathrm{C}$. Helminth eggs were determined using EPA method 9132, and total coliform was counted using the violet bile red Petrifilm plates (3M, USA) with tetrazolium as the indicator at $37^{\circ} \mathrm{C}$ for 48 hours; the sludge samples were diluted at 1:100 with sterile peptone water because sludge is characterized by a dark color. 


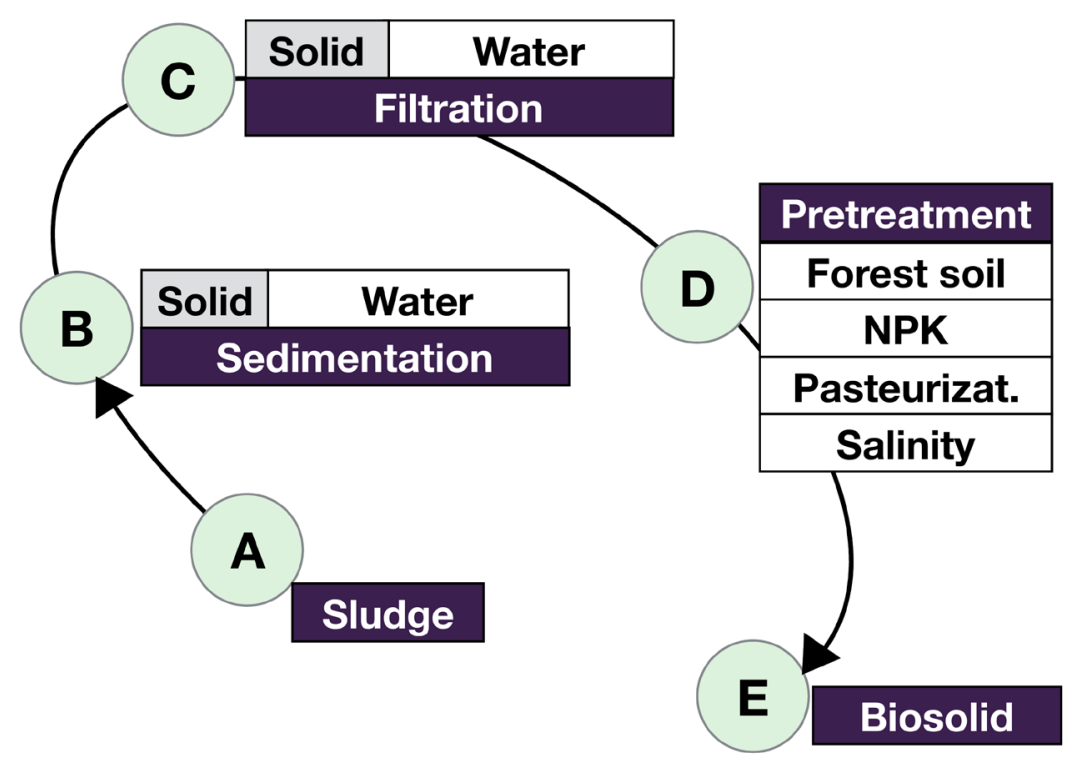

Figure 1. Biostabilization process

\section{RESULTS AND DISCUSSION}

\section{Effect on $\mathrm{pH}$ and temperature}

Different pre-treatment conditions using premontane forest soil, NPK, $\mathrm{NaCl}$, and pasteurization changed $\mathrm{pH}$ from 6.0-6.5 to 7.0-7.5 during 30 days of biostabilization, as indicated in Figure 2. According to the results, $\mathrm{pH}$ changes due to the microbial decarboxylation of organic anions, heterocyclic compounds, and volatile fatty acids, suggesting that stability was reached $(\mathrm{Wu}, \mathrm{Ma}$, and Martinez, 2000; Yuan and Zhu, 2016). Normally, the first days in the anaerobic digestion are the rate-limiting step because of the hydrolysis of insoluble organic matter into a soluble form, which influences the further stabilization kinetics (Eastman and Ferguson, 1981; Parkin et al., 1986). The addition of forest soil, NPK, and $\mathrm{NaCl}$ boosted the release of microbial exoenzymes to cleave macromolecules like triglycerides, diglycerides, and fatty acids (Harris and McCabe, 2015). Thus, the more carbon is solubilized, the faster the stabilization process. Therefore, pretreatments focused on hydrolysis maximize the degradation rate until mineralization of organic matter occurred. A drop in $\mathrm{pH}$ shows an increase of volatile fatty acids as acetic acid or propionic acid, which could be a problem in the stabilization process (Ahring et al., 1995; Amani et al., 2010; Berktay and Nas, 2007; Carrère et al., 2010; Harris and McCabe, 2015). In our case, the acid phase lasted for about 15 days, which is an indicator of hydrolysis without interruption of the high fatty acid concentrations or non-biodegradable (refractory) components. At the end of the process (Fig. 2), the pH was 7.0-7.5 due to the microbial ammonification when ammonium compounds are nitrified to nitrate (Cofie et al., 2016).

In Figure 3, the temperature remained between $30-37^{\circ} \mathrm{C}$ in all treatments while the control reaction remained at approx. $20^{\circ} \mathrm{C}$. One pretreatment involved pasteurization at $70^{\circ} \mathrm{C}$ for 30 minutes, which is used to improve the organics solubilization to provide a carbon source for microorganisms (Weemaes and Verstraete, 1998). In this way, high temperatures expose macromolecules to achieve their breakdown and further ease the degradation by thermophilic microorganisms (Carrère et al., 2010; Harris and McCabe, 2015). Since the mesophilic digestion does not kill pathogens efficiently, the thermal hydrolysis at $70^{\circ} \mathrm{C}$ was utilized as another kind of disinfection technique (Oleszkiewicz and Mavinic, 2002). The thermophilic digestion is up to three-fold higher than the mesophilic one, which enhances the hydrolysis conversion rates with an impact of higher volumetric biogas production at a lower hydraulic retention time (HRT) (De Vrieze et al., 2016). However, in economic terms, the mesophilic temperatures are more stable and have lower energy costs than the thermophilic treatments (Braguglia et al., 2015). Moreover, a mesophilic process is less inhibited by ammonium and longchain fatty acids (LCFA) (Fernández-Rodríguez et al., 2015). According to Figure 4, the process started almost at $45^{\circ} \mathrm{C}$ and had an acidic pH dur- 


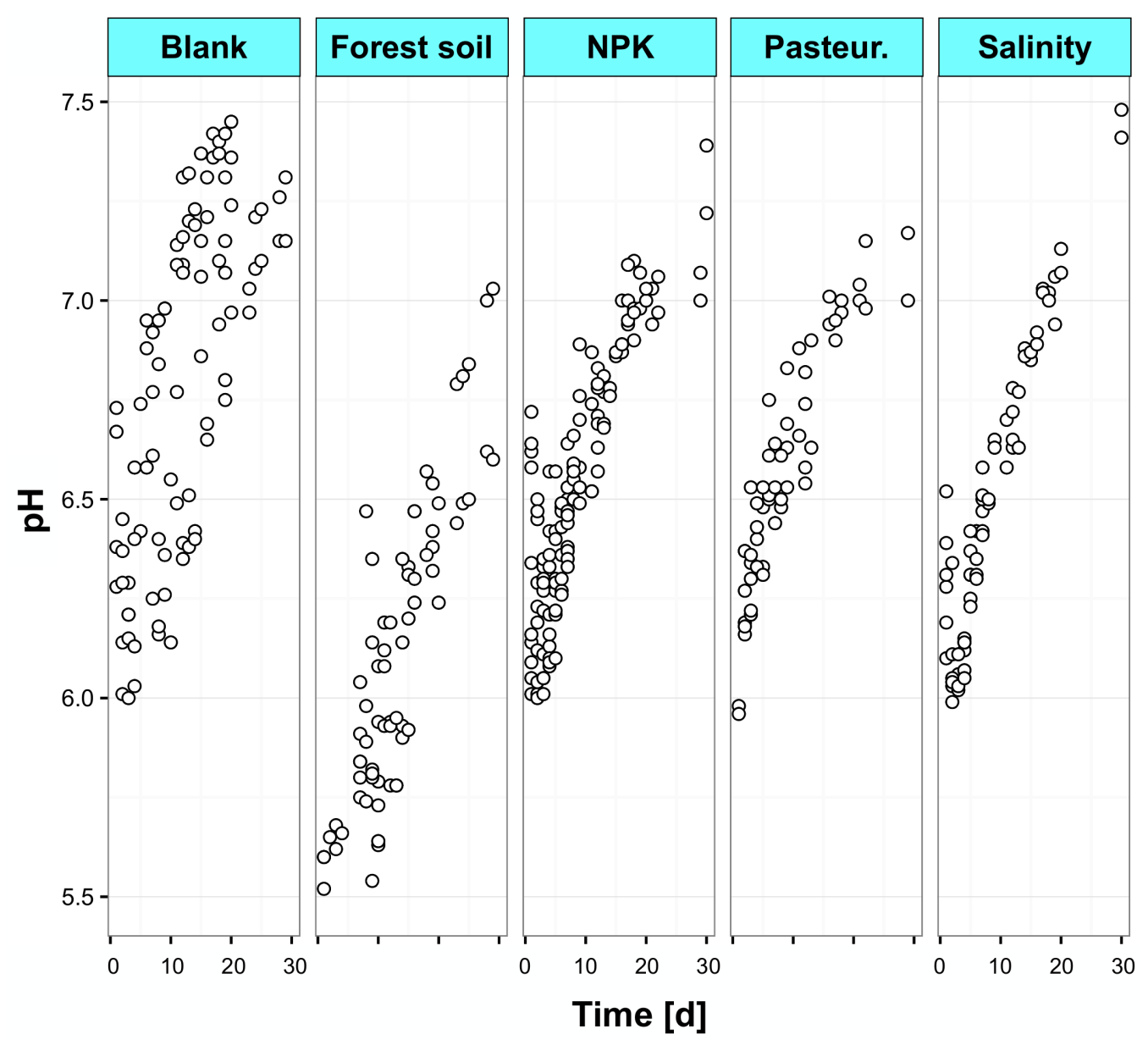

Figure 2. Effect of different biostabilization pre-treatments on $\mathrm{pH}$ during 30 days

ing the first few days, which favored the growth of fungi and actinomycetes. However, afterwards, a neutral $\mathrm{pH}$ and a temperature close to ambient temperature $\left(20^{\circ} \mathrm{C}\right)$ were obtained. Together, $\mathrm{pH}$ and temperature progressively interacted due to high microbial activity during a solid residence time (SRT) of 30 days at $20-45^{\circ} \mathrm{C}$. Thus, SRT and the mesophilic range in our biostabilization process performed according to the EPA regulations for biosolids under class B (Mustafa et al., 2014).

\section{Gravimetric evolution}

One method to evaluate biostabilization is to measure the change in total solids (TS) and volatile solids (VS), which is herein recognized as gravimetric evolution. Over a period of 30 days, the content of TS and VS changed dramatically, and showed tendencies that demonstrated biostabilization (Fig. 4). The content of organic matter is virtually represented by VS, and its reduction is due to the microbial mineralization and the conversion of organic matter into humic substances (Gómez et al., 2005; Otero et al., 2002). The measurement of volatile solids destruction is an indicator of the mineralization degree of organic carbon to mineral forms like $\mathrm{CO}_{2}$ or $\mathrm{CH}_{4}$ (Ahring et al., 1995; Bernal et al., 1998). According to VS destruction, the USEPA uses the value of $38 \%$ reduction in the threshold for considering the sludge to be stabilized (Environmental Protection Agency, 1994; Oleszkiewicz and Mavinic, 2002). In Figure 4, the VS/ TS relationship is presented. Due to the low mineralization rate of the organic nitrogen found in sludge, enrichment with minerals like nitrogen, phosphorous, potassium and bacterial inoculant (forest soil) enhances the microbial activity and further organic matter degradation (Cofie et al., 2016). Our results confirm that nutrients, forest soil, thermal treatment, and even salinity are the enhancers of VS reduction (Bhattacharya et al., 1996; Ruffino et al., 2015).

In Figure 5, the gravimetric evolution of VS/ TS is shown in every treatment. The control treatment (blank) did not overcome the stability range 


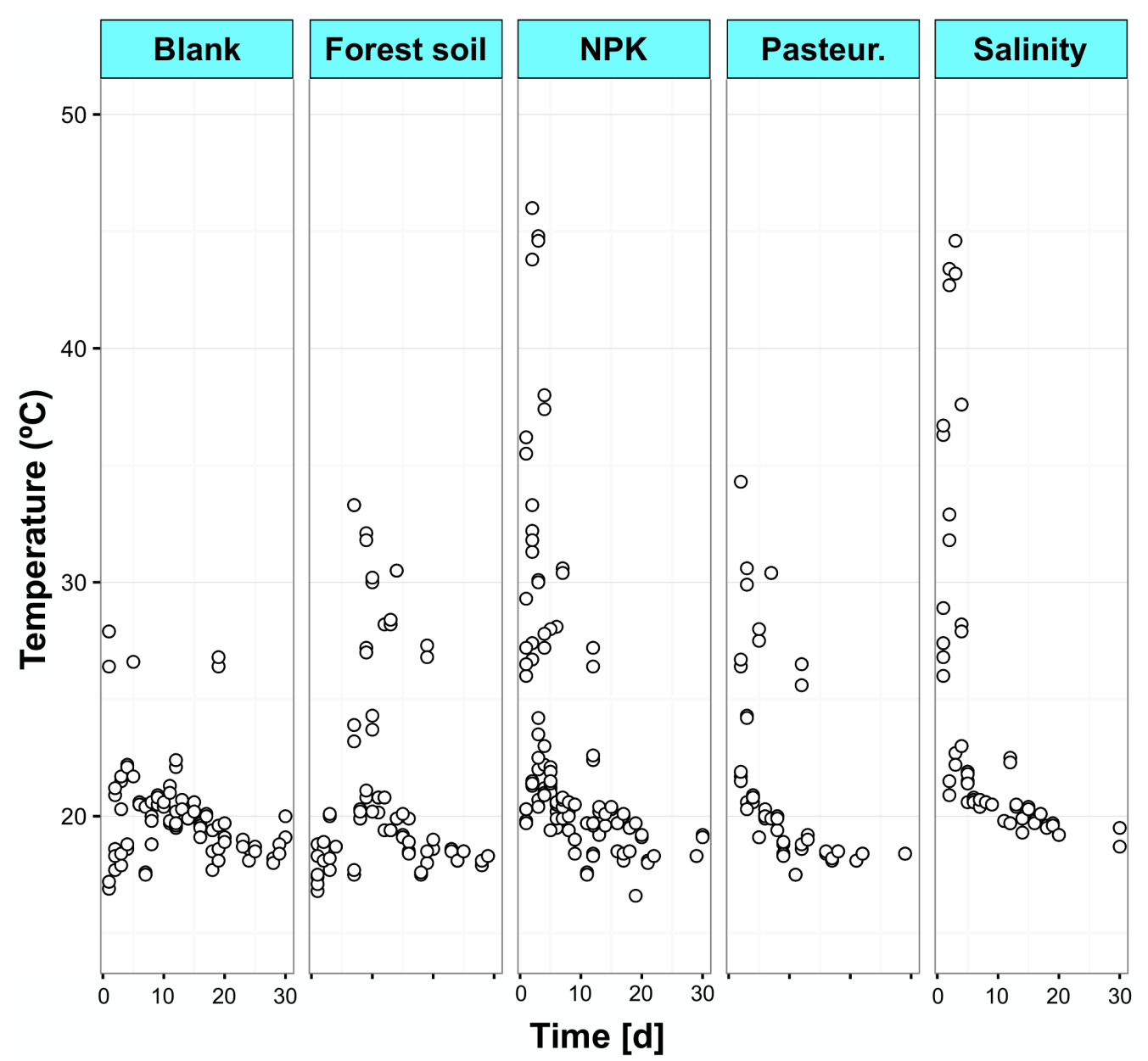

Figure 3. Effect of different biostabilization pre-treatments on temperature during 30 days

above $11.4 \%$ VS reduction. The forest soil, as a pre-digestion treatment, reduced $55.7 \% \mathrm{VS} / \mathrm{TS}$ because the more diverse the microbes, the faster digestion occurs. The pre-treatment that used forest soil and NPK nutrients, altogether reduced by $87.3 \%$ the VS/TS content. An optimal pre-treatment was also using pasteurization, in which an $87.2 \% \mathrm{VS} / \mathrm{TS}$ reduction was obtained. The pretreatment with $\mathrm{NaCl}$ destroyed the VS content just by $36.7 \%$; in this case, $\mathrm{NaCl}$ inhibited the microbial growth.

According to the results shown in Figure 5, a first order kinetic was obtained in two pre-treatments (Bernal et al., 1998). Forest soil enhanced a first order kinetic $\left(\mathrm{k}=0.02930, \mathrm{R}^{2}=0.9312\right.$, $\mathrm{p}<0.05)$, as well as NPK $\left(\mathrm{k}=0.064, \mathrm{R}^{2}=0.9706\right.$, $\mathrm{p}<0.05)$. On the other hand, a second order kinetic was observed in the pre-treatments using pasteurization $\left(\mathrm{k}=0.2390, \mathrm{R}^{2}=0.9833, \mathrm{p}<0.05\right)$ and salinity $\left(\mathrm{k}=0.0262, \mathrm{R}^{2}=0.9486, \mathrm{p}<0.05\right)$. Thus, faster kinetics reduces the size of the reactor and decreases hydraulic retention time (HRT) (Carrère et al., 2010).
According to the literature, the mesophilic digestion requires over a 20-day retention time, and it is not as efficient as the thermophilic process (Rulkens, 2008; Song et al., 2004). However, in the present work, the change of VS/TS in pre-treatments using forest soil, NPK, and pasteurization was up to $87 \%$, which shows that mesophilic digestion can be optimal as the thermophilic counterpart.

\section{Heavy metals}

Table 1 shows the reduction in the heavy metal content through the biostabilization process in comparison with the EPA permissible limits. Ac-

Table 1. Chemical characterization before and after the biostabilization process

\begin{tabular}{|c|c|c|c|}
\hline Parameter & $\begin{array}{c}\text { Sludge } \\
(\mathrm{mg} / \mathrm{kg})\end{array}$ & $\begin{array}{c}\text { Biosolid } \\
(\mathrm{mg} / \mathrm{kg})\end{array}$ & EPA $(\mathrm{mg} / \mathrm{kg})$ \\
\hline $\mathrm{As}$ & 0.170 & 0.010 & 41 \\
\hline $\mathrm{Cd}$ & 0.110 & 0.025 & 85 \\
\hline $\mathrm{Hg}$ & 0.002 & 0.001 & 57 \\
\hline $\mathrm{Pb}$ & 2.080 & 0.400 & 840 \\
\hline
\end{tabular}




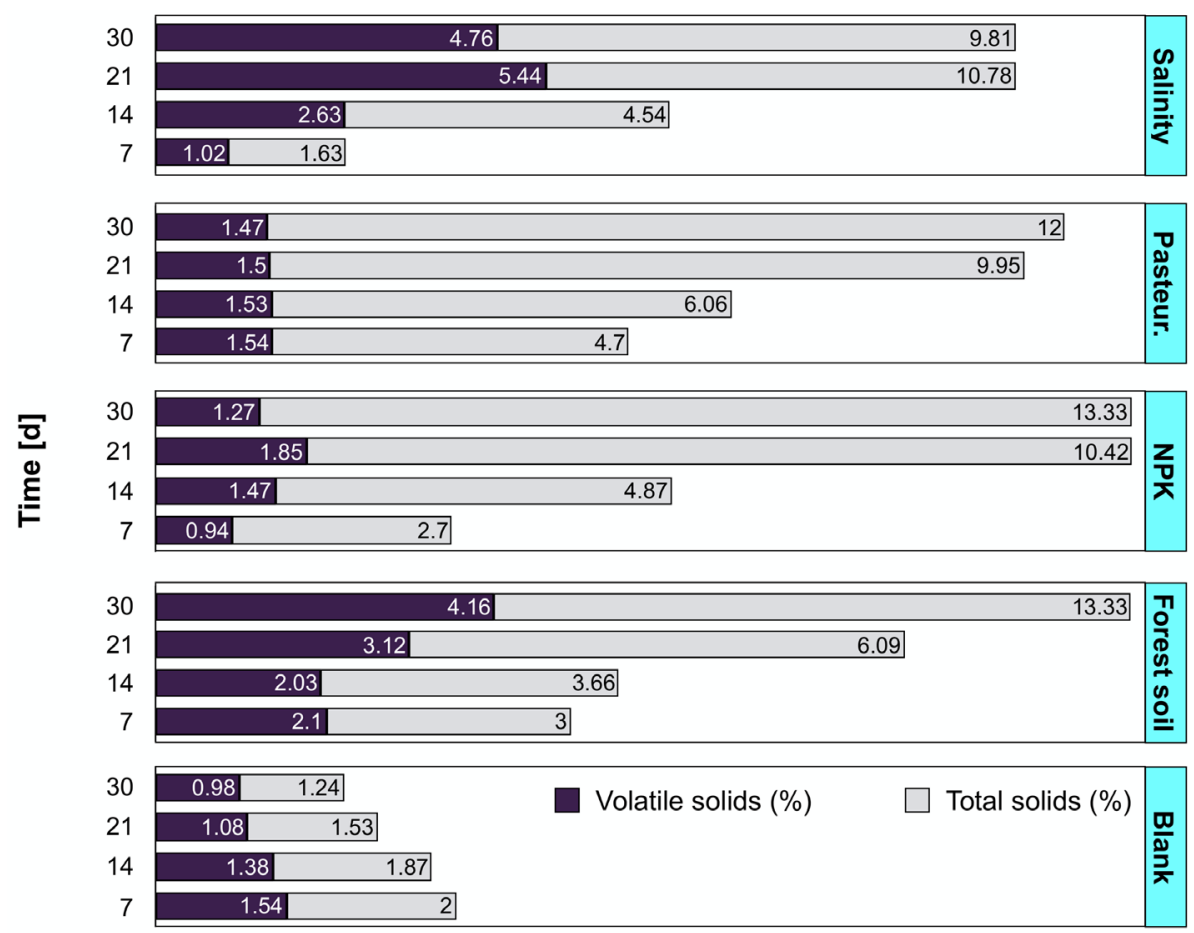

Figure 4. Change in TS and VS (\%) during 30 days
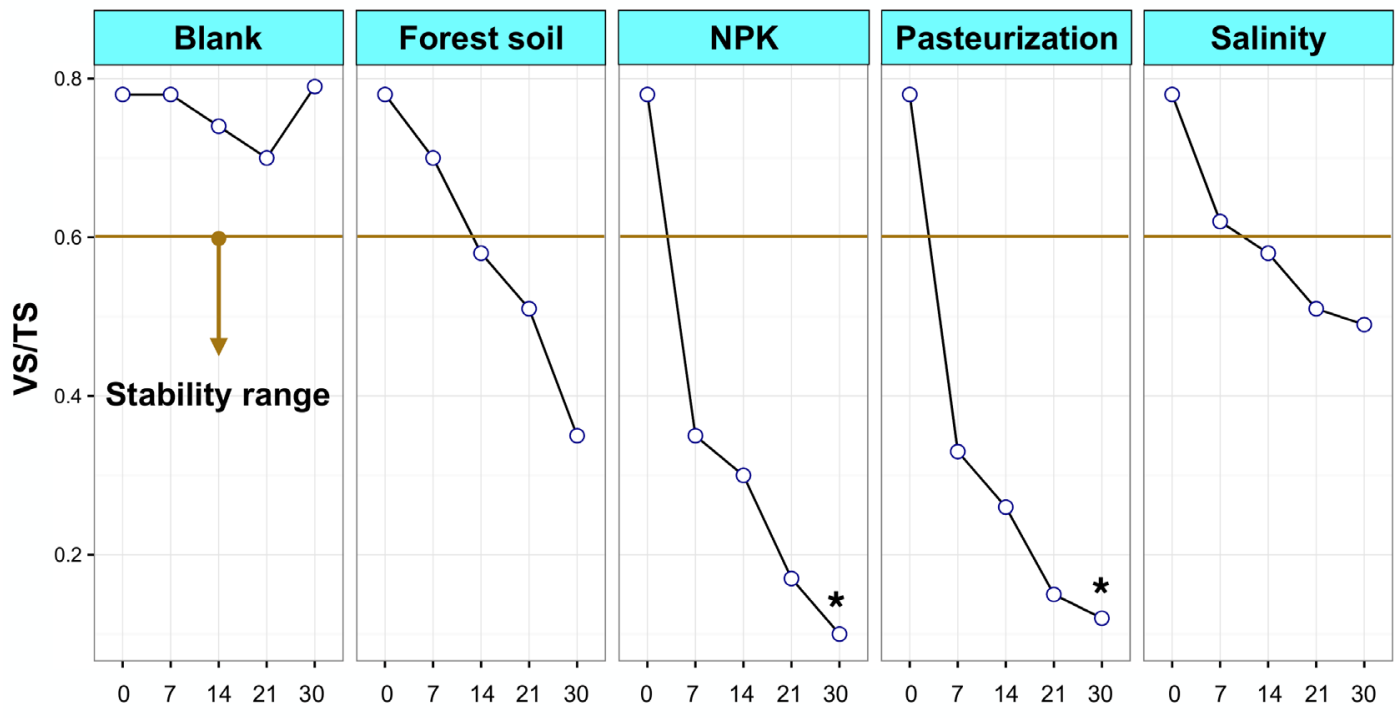

Time [d]

Figure 5. Gravimetric evolution (VS/TS) at different pre-treatments during 30 days

cording to the results, the order of metal content at the end of biostabilization was $\mathrm{Pb}>\mathrm{Cd}>\mathrm{As}$ $>\mathrm{Hg}$. The concentrations of $\mathrm{Pb}, \mathrm{Cd}, \mathrm{As}$, and $\mathrm{Hg}$ decreased by $94.1 \%, 77.3 \%, 50 \%$, and $80.8 \%$, respectively. The reduction of the total concentrations of heavy metals in biosolids is significant due to dilution during the mixing process with forest soil; therefore, the concentrations are under the EPA regulation limits. However, the bioavailability and toxicity of heavy metals in the sludge depend on their chemical forms and $\mathrm{pH}$, which in consequence will precipitate with carbonate minerals, complexes and organic ligands at basic $\mathrm{pH}$ (Dong et al., 2013).

\section{Pathogen removal}

We measured the remaining digestion of samples in $\mathrm{mg} / \mathrm{L}$ over nine days after the 30-day of biostabilization process to test any microbial 


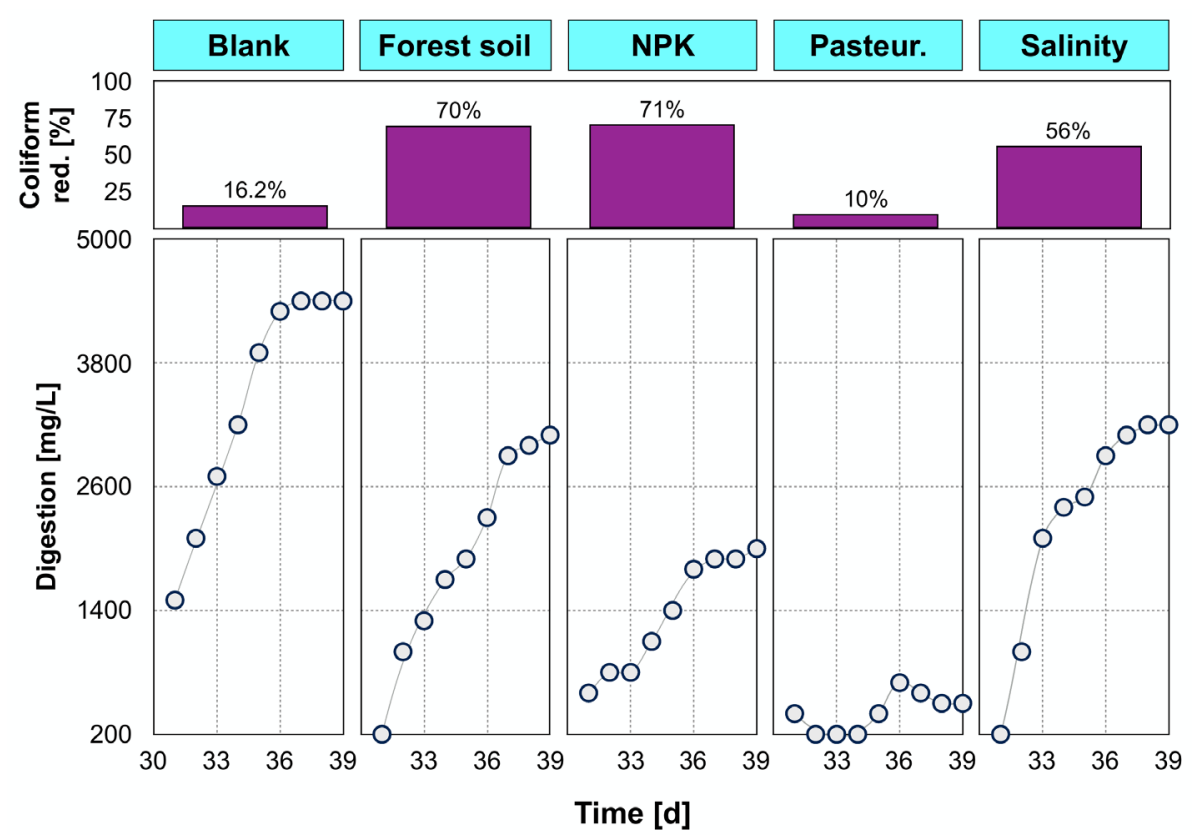

Figure 6. Digestion of sludge samples after the biostabilization process
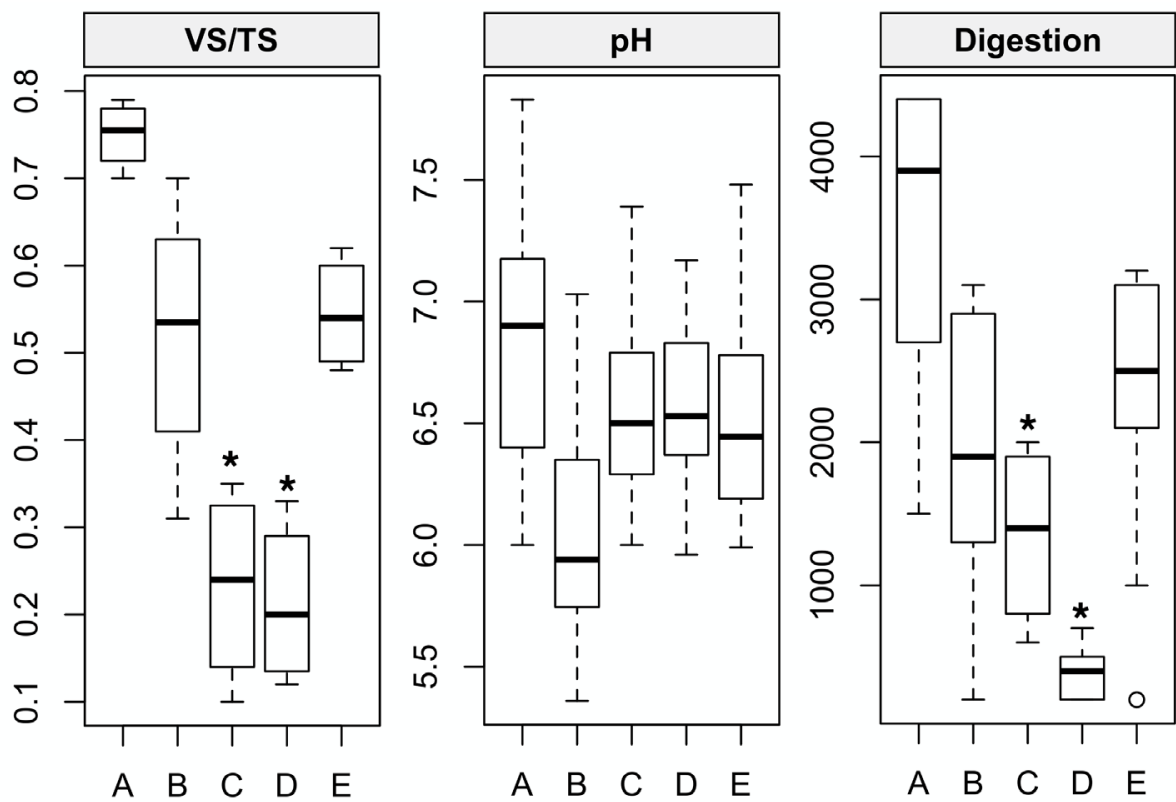

Treatments

Figure 7. Results of the biostabilization process; (A) blank sample, (B) forest soil, (C) NPK, (D) pasteurization and (E) salinity treatment

activity (Figure 6). After the VS destruction, the $\mathrm{CO}_{2}$ production rate should decrease, along with the pathogen removal (Wu et al., 2000). Both digestion and coliform reduction were examined to test which treatment was the most efficient way to stabilize sludge through pathogen reduction. The colony-forming units (CFU) per $\mathrm{mL}$ were 31700, 26550, 9650, 9150, 28500, and 13700 for blank, forest soil, NPK, pasteurization, and salin- ity treatments, respectively. According to the results, the order of coliform reduction at the end of biostabilization was NPK $>$ forest soil $>$ salinity $>$ blank $>$ pasteurization, and the removal of coliforms was reduced by $71 \%, 70 \%, 56 \%, 16.2 \%$, and $10 \%$, respectively. In the present case, the best pre-treatment utilized NPK and forest soil.

According to the results, our biosolid is classified as class B because the US EPA recom- 
mends a VS reduction by $38 \%$ and a mean coliform density of less than 2 million CFU per gram of biosolids (Environmental Protection Agency, 1994). Although a biosolid might be recognized as freshly processed class B, sewage sludges may pose a significant risk of infection due to the pathogen regrowth, and this is why such biosolids should be managed with great care to public access (Gattie and Lewis, 2003). In order to adhere to the human health standards, different treatment methods should demonstrate the ability to neutralize the pathogen viability.

Figure 7 presents the biostabilization results in box plots. The pre-treatments using forest soil as bio-accelerator, NPK and pasteurization stabilized sewage sludge up to $87 \%$ in VS/TS reduction. All treatments, except the forest soil one, got a $\mathrm{pH}$ between 6.5 and 7 . No significant benefit was obtained by the $\mathrm{NaCl}$ treatment.

\section{CONCLUSIONS}

The legal constraints to using sewage sludge in agriculture and further land applications motivate the search for cheaper stabilization processes and therefore avoiding incineration as the final option for sewage disposal. In the present study, the use of the proper combination of nutrition and temperature enhanced the performance of sludge biostabilization. However, to improve the digestion efficiency, a pasteurization process should be conducted at a higher temperature in a shorter time. According to the results obtained in this work, the further research outlook is focused on the high reduction of pathogen count.

\section{Acknowledgment}

The authors thank lab specialists Javier Álava and Pavlova Sigcha from UDLA for their assistance in all experiments.

\section{REFERENCES}

1. Ahring, B.K., Sandberg, M., and Angelidaki, I. 1995. Volatile fatty acids as indicators of process imbalance in anaerobic digestors. Applied Microbiology and Biotechnology, 43(3), 559-565.

2. Amani, T., Nosrati, M., and Sreekrishnan, T.R. 2010. Anaerobic digestion from the viewpoint of microbiological, chemical, and operational aspects - a review. Environmental Reviews, 18(NA), 255-278.
3. Barrios, J.A., Becerril, E., De León, C., BarreraDíaz, C. and Jiménez, B. 2015. Electrooxidation treatment for removal of emerging pollutants in wastewater sludge. Fuel, 149, 26-33.

4. Berktay, A., and Nas, B. 2007. Biogas Production and Utilization Potential of Wastewater Treatment Sludge. Energy Sources, Part A: Recovery, Utilization, and Environmental Effects, 30(2), 179-188. https://doi.org/10.1080/00908310600712489

5. Bernal, M.P., Sanchez-Monedero, M.A., Paredes, C., and Roig, A. 1998. Carbon mineralization from organic wastes at different composting stages during their incubation with soil. Agriculture, Ecosystems and Environment, 69(3), 175-189.

6. Bhattacharya, S.K., Madura, R.L., Walling, D.A., and Farrell, J.B. 1996. Volatile solids reduction in two-phase and conventional anaerobic sludge digestion. Water Research, 30(5), 1041-1048.

7. Braguglia, C.M., Gianico, A., Gallipoli, A., and Mininni, G. 2015. The impact of sludge pre-treatments on mesophilic and thermophilic anaerobic digestion efficiency: Role of the organic load. Chemical Engineering Journal, 270, 362-371.

8. Bright, D.A., and Healey, N. 2003. Contaminant risks from biosolids land application. Environmental Pollution, 126(1), 39-49. https://doi. org/10.1016/S0269-7491(03)00148-9

9. Cain, G. D. (2010). Sanitizing Sewage Sludge: The Intersection of Parasitology, Civil Engineering, and Public Health. Journal of Parasitology, 96(6), 1037-1040. https://doi.org/10.1645/GE-2631.1

10. Carrère, H., Dumas, C., Battimelli, A., Batstone, D.J., Delgenès, J.P., Steyer, J.P., and Ferrer, I. 2010. Pretreatment methods to improve sludge anaerobic degradability: A review. Journal of Hazardous Materials, 183(1-3), 1-15. https://doi.org/10.1016/j. jhazmat.2010.06.129

11. Cofie, O., Nikiema, J., Impraim, R., Adamtey, N., Paul, J., and Kone, D. 2016. Co-composting of solid waste and fecal sludge for nutrient and organic matter recovery: Retrieved from https://books. google.com.ec/books?id=QrukDQAAQBAJ

12. De Vrieze, J., Smet, D., Klok, J., Colsen, J., Angenent, L.T., and Vlaeminck, S.E. 2016. Thermophilic sludge digestion improves energy balance and nutrient recovery potential in full-scale municipal wastewater treatment plants. Bioresource Technology, 218, 1237-1245.

13. Dong, B., Liu, X., Dai, L., and Dai, X. 2013. Changes of heavy metal speciation during highsolid anaerobic digestion of sewage sludge. Bioresource Technology, 131, 152-158.

14. Eastman, J.A., and Ferguson, J.F. 1981. Solubilization of particulate organic carbon during the acid phase of anaerobic digestion. Journal (Water Pollution Control Federation), 352-366. 
15. Egan, M. 2013. Biosolids management strategies: an evaluation of energy production as an alternative to land application. Environmental Science and Pollution Research, 20(7), 4299-4310. https:// doi.org/10.1007/s11356-013-1621-1

16. Environmental Protection Agency 1994. A Plain English Guide to the EPA Part 503 Biosolids Rule. Retrieved from https:/www.epa.gov/biosolids/

17. Fernández-Rodríguez, J., Pérez, M., and Romero, L.I. 2015. Temperature-phased anaerobic digestion of Industrial Organic Fraction of Municipal Solid Waste: A batch study. Chemical Engineering Journal, 270, 597-604. https://doi.org/10.1016/j. cej.2015.02.060

18. Fytili, D., and Zabaniotou, A. 2008. Utilization of sewage sludge in EU application of old and new methods - A review. Renewable and Sustainable Energy Reviews, 12(1), 116-140. https://doi. org/10.1016/j.rser.2006.05.014

19. Gattie, D.K., and Lewis, D.L. 2003. A HighLevel Disinfection Standard for Land-Applied Sewage Sludges (Biosolids). Environmental Health Perspectives, 112(2), 126-131. https://doi. org/10.1289/ehp.6207

20. Gerba, C.P., Ross, A., Takizawa, K., and Pepper, I.L. 2011. Efficiency of ASTM Method D4994-89 for Recovery of Enteric Viruses from Biosolids. Food and Environmental Virology, 3(1), 43-45. https://doi.org/10.1007/s12560-011-9054-9

21. Gómez, X., Cuetos, M.J., García, A.I., and Morán, A. 2005. Evaluation of digestate stability from anaerobic process by thermogravimetric analysis. Thermochimica Acta, 426(1-2), 179-184. https:// doi.org/10.1016/j.tca.2004.07.019

22. Hale, R.C., La Guardia, M.J., Harvey, E.P., Gaylor, M.O., Mainor, T.M., and Duff, W.H. 2001. Flame retardants: Persistent pollutants in land-applied sludges. Nature, 412(6843), 140-141. https://doi. org/10.1038/35084130

23. Harris, P.W., and McCabe, B.K. 2015. Review of pre-treatments used in anaerobic digestion and their potential application in high-fat cattle slaughterhouse wastewater. Applied Energy, 155, 560-575. https://doi.org/10.1016/j.apenergy.2015.06.026

24. Jenicek, P., Bartacek, J., Kutil, J., Zabranska, J., and Dohanyos, M. 2012. Potentials and limits of anaerobic digestion of sewage sludge: Energy self-sufficient municipal wastewater treatment plant? Water Science and Technology, 66(6), 1277. https://doi.org/10.2166/wst.2012.317

25. Kinney, C.A., Furlong, E.T., Zaugg, S.D., Burkhardt, M.R., Werner, S.L., Cahill, J.D., and Jorgensen, G.R. 2006. Survey of Organic Wastewater Contaminants in Biosolids Destined for Land Application. Environmental Science and Technology, 40(23), 7207-7215. https://doi.org/10.1021/ es0603406
26. Krach, K.R., Burns, B.R., Li, B., Shuler, A., Cole, C., and Xie, Y. 2008. Odor Control for Land Application of Lime Stabilized Biosolids. Water, Air, and Soil Pollution: Focus, 8(3-4), 369-378. https:// doi.org/10.1007/s11267-007-9147-5

27. Krüger, O., Grabner, A., and Adam, C. 2014. Complete Survey of German Sewage Sludge Ash. Environmental Science and Technology, 48(20), 11811-11818. https://doi.org/10.1021/es502766x

28. Lewis, D.L., Garrison, A.W., Wommack, K.E., Whittemore, A., Steudler, P., and Melillo, J. 1999. Influence of environmental changes on degradation of chiral pollutants in soils. Nature, 401(6756), 898-901. https://doi.org/10.1038/44801

29. Lewis, D.L., Gattie, D.K., Novak, M.E., Sanchez, S., and Pumphrey, C. 2002. Interactions of pathogens and irritant chemicals in land-applied sewage sludges (biosolids). BMC Public Health, 2(1), 11.

30. Li, X., Brown, D.G., and Zhang, W. 2007. Stabilization of biosolids with nanoscale zero-valent iron (nZVI). Journal of Nanoparticle Research, 9(2), 233-243. https://doi.org/10.1007/ s11051-006-9187-1

31. Mu, D., Addy, M., Anderson, E., Chen, P., and Ruan, R. 2016. A life cycle assessment and economic analysis of the Scum-to-Biodiesel technology in wastewater treatment plants. Bioresource Technology, 204, 89-97. https://doi.org/10.1016/j. biortech.2015.12.063

32. Mulla, S.I., Wang, H., Sun, Q., Hu, A., and Yu, C.P. 2016. Characterization of triclosan metabolism in Sphingomonas sp. strain YL-JM2C. Scientific Reports, 6(1). https://doi.org/10.1038/srep21965

33. Mustafa, N., Elbeshbishy, E., Nakhla, G., and Zhu, J. 2014. Anaerobic digestion of municipal wastewater sludges using anaerobic fluidized bed bioreactor. Bioresource Technology, 172, 461-466. https://doi.org/10.1016/j.biortech.2014.09.081

34. Oleszkiewicz, J.A., and Mavinic, D.S. 2002. Wastewater biosolids: an overview of processing, treatment, and management. Journal of Environmental Engineering and Science, 1(2), 75-88. https://doi.org/10.1139/s02-010

35. Oron, G., Adel, M., Agmon, V., Friedler, E., Halperin, R., Leshem, E., and Weinberg, D. 2014. Greywater use in Israel and worldwide: Standards and prospects. Water Research, 58, 92-101. https:// doi.org/10.1016/j.watres.2014.03.032

36. Otero, M., Calvo, L.F., Estrada, B., Garcia, A.I., and Moran, A. 2002. Thermogravimetry as a technique for establishing the stabilization progress of sludge from wastewater treatment plants. Thermochimica Acta, 389(1), 121-132.

37. Parkin Gene F., and Owen William F. 1986. Fundamentals of Anaerobic Digestion of Wastewater Sludges. Journal of Environmental Engineer- 
ing, 112(5), 867-920. https://doi.org/10.1061/ (ASCE)0733-9372(1986)112:5(867)

38. Rogers, H.R. 1996. Sources, behaviour and fate of organic contaminants during sewage treatment and in sewage sludges. Science of the Total Environment, 185(1), 3-26.

39. Ruffino, B., Campo, G., Genon, G., Lorenzi, E., Novarino, D., Scibilia, G., and Zanetti, M. 2015. Improvement of anaerobic digestion of sewage sludge in a wastewater treatment plant by means of mechanical and thermal pre-treatments: Performance, energy and economical assessment. Bioresource Technology, 175, 298-308. https://doi. org/10.1016/j.biortech.2014.10.071

40. Rulkens, W. 2008. Sewage Sludge as a Biomass Resource for the Production of Energy: Overview and Assessment of the Various Options ${ }^{\dagger}$. Energy and $\mathrm{Fu}-$ els, 22(1), 9-15. https://doi.org/10.1021/ef700267m

41. Singh, R.P., and Agrawal, M. 2008. Potential benefits and risks of land application of sewage sludge. Waste Management, 28(2), 347-358. https://doi. org/10.1016/j.wasman.2006.12.010

42. Snowden-Swan, L.J., Hallen, R.T., Zhu, Y., Billing, J.M., Jones, S.B., Hart, T.R., et al. 2016. Hydrothermal Liquefaction and Upgrading of $\mathrm{Mu}-$ nicipal Wastewater Treatment Plant Sludge: A Preliminary Techno-Economic Analysis. Pacific Northwest National Laboratory (PNNL), Richland, WA (US). Retrieved from http://www.pnnl. gov/main/publications/external/technical_reports/ PNNL-25464Rev1.pdf

43. Song, Y.-C., Kwon, S.-J., and Woo, J.-H. 2004. Mesophilic and thermophilic temperature co-phase anaerobic digestion compared with single-stage mesophilic- and thermophilic digestion of sewage sludge. Water Research, 38(7), 1653-1662. https:// doi.org/10.1016/j.watres.2003.12.019

44. Stasinakis, A.S. 2012. Review on the fate of emerging contaminants during sludge anaerobic digestion. Bioresource Technology, 121, 432-440. https://doi.org/10.1016/j.biortech.2012.06.074

45. Tchobanoglous, G., Burton, F.L., and Stensel, H.D. 2013. Wastewater Engineering: Treatment and Resource Recovery. McGraw-Hill Education. Retrieved from https://books.google.com.ec/ books?id=BL3wjgEACAAJ

46. Venkatesan, A.K., and Halden, R.U. 2014. Wastewater Treatment Plants as Chemical Observatories to Forecast Ecological and Human Health Risks of Manmade Chemicals. Scientific Reports, 4. https:// doi.org/10.1038/srep03731

47. Wang, H., Brown, S.L., Magesan, G.N., Slade, A.H., Quintern, M., Clinton, P.W., and Payn, T.W. (2008a). Technological options for the management of biosolids. Environmental Science and Pol- lution Research - International, 15(4), 308-317. https://doi.org/10.1007/s11356-008-0012-5

48. Wang, H., Brown, S.L., Magesan, G.N., Slade, A.H., Quintern, M., Clinton, P.W., and Payn, T.W. 2008b. Technological options for the management of biosolids. Environmental Science and Pollution Research - International, 15(4), 308-317. https:// doi.org/10.1007/s11356-008-0012-5

49. Wang, L.K., Hung, Y.-T., and Shammas, N.K. 2007. Biosolids Treatment Processes. Totowa (NJ): Humana Press.

50. Weemaes, M.P.J., and Verstraete, W.H. 1998. Evaluation of current wet sludge disintegration techniques. Journal of Chemical Technology and Biotechnology, 73(2), 83-92.

51. Wei, Y., Van Houten, R.T., Borger, A.R., Eikelboom, D.H., and Fan, Y. 2003. Minimization of excess sludge production for biological wastewater treatment. Water Research, 37(18), 4453-4467. https://doi.org/10.1016/S0043-1354(03)00441-X

52. Wu, L., Ma, L., and Martinez, G. 2000. Comparison of methods for evaluating stability and maturity of biosolids compost. Journal of Environmental Quality, 29(2), 424-429.

53. Ye, F., Liu, X., and Li, Y. 2014. Extracellular polymeric substances and dewaterability of waste activated sludge during anaerobic digestion. Water Science and Technology, 70(9), 1555.

54. Yuan, H., and Zhu, N. 2016. Progress in inhibition mechanisms and process control of intermediates and by-products in sewage sludge anaerobic digestion. Renewable and Sustainable Energy Reviews, 58, 429-438. https://doi.org/10.1016/j. rser.2015.12.261

55.Zahan, Z., Othman, M.Z., and Rajendram, W. 2016. Anaerobic Codigestion of Municipal Wastewater Treatment Plant Sludge with Food Waste: A Case Study. BioMed Research International, 2016, 1-13. https://doi.org/10.1155/2016/8462928 